\title{
Haematological Parameters in Patients with Alcohol Dependence Syndrome
}

\author{
Dr. Chandini ${ }^{1}$, Dr. P. John Mathai ${ }^{2}$ \\ ${ }^{I}$ (Assistant Professor, Department of Psychiatry, Father Muller Medical College Mangalore, India) \\ ${ }_{2}^{2}$ (Professor and Head, Department of Psychiatry, Jubilee Mission Medical College and Research Institute \\ Kerala; Former Professor and Head, Department of Psychiatry, Father Muller Medical College, India)
}

\begin{abstract}
:
Objective: Alcohol has direct toxic effect on bone marrow and also indirect effect on precursors of all blood cells - red blood cells, platelets and white blood cells. Long term excessive alcohol consumption can interfere with various physiological, biochemical and metabolic processes of the blood cells. The medical consequences of haematological abnormalities can be severe and debilitating. The aim of this study is to evaluate frequency and nature of haematological parameters in inpatients with alcohol dependence syndrome and to study the relationship between haematological parameters and clinical variables.

Methods: This is an observational, descriptive, cross sectional clinical study conducted on one hundred consecutive patients with ICD10 diagnosis of Alcohol Dependence Syndrome admitted to the deaddiction centre, Department of Psychiatry, Father Muller Medical College Mangalore. Laboratory investigations were done for all inpatients to assess for haematological parameters. Medical diagnosis was based on clinical findings and examination. The data of 100 patients were analyzed using chi-square test, Fischer's Exact Test and Karl Pearson co-relation co-efficient.

Results: 100 patients with alcohol dependence syndrome were assessed for haematological parameters of which $36 \%$ of individuals have hemoglobin level less than $12 \mathrm{~g} / \mathrm{dl}$. $11 \%$ of individuals have increased white blood cells and 7\% of individual have decreased white blood cells count. 27\% of individual have raised Erythrocyte Sedimentation Rate. $60 \%$ of individuals with alcohol dependence syndrome have reduced platelet counts.

Conclusion: Increasing prevalence of haematological abnormalities is observed in patients with alcohol dependence syndrome. Our findings substantiate the importance for assessment of haematological parameters in patients with alcohol dependence syndrome. The direct and indirect effects of alcohol can result in serious medical complications.
\end{abstract}

Keywords: Alcohol Dependence Syndrome, Anaemia, Thrombocytopenia.

\section{Introduction}

Higher prevalence of medical co morbidity and haematological abnormalities are well recognized in individuals with alcohol dependence syndrome. Researchers have reported that alcohol consumption was associated with abnormalities of red blood cells, platelets and white blood cells and has various effects on haematological conditions including macrocytosis with or without anaemia, leucopenia, anaemia, thrombocytopenia, marrow erythroid disorders and others. ${ }^{[1]}$ The direct consequences of excessive alcohol consumption include toxic effects on the bone marrow, the blood cell precursors, the mature red blood cells, white blood cells, platelets and also abnormalities in membrane phospholipids and interference with folate utilization. Indirect effects of alcohol include nutritional deficiencies that impair the production and functions of various blood cells. Interfering with the proper absorption of iron into the hemoglobin molecules of red blood cells, alcohol use can lead to either iron deficiency or excessively high levels of iron in the body. ${ }^{[2]}$

Researchers have found that individuals with chronic consumption of alcohol have a high value of erythrocyte Mean Corpuscular Volume, which was $22.7 \%$. A high erythrocyte mean cell distribution width value indicating anisocytosis was found in $40.6 \%$ of subjects. The percentage of hemoglobin and total number of red blood cells was found to be significantly decreased. ${ }^{[3,4]}$ It was also observed that patients with chronic alcohol consumption was associated with iron deficiency anaemia, alcohol-induced haemolytic anaemia with liver damage ${ }^{[5,6]}$ Haematological studies conducted on 65 consecutive patients with alcohol dependence syndrome found that $75 \%$ of the patients had disorders of red blood cells production, $40 \%$ had megaloblastic erythropoiesis secondary to folic acid deficiency, $30 \%$ had ring sideroblastic defect of the marrow and also other causes of anaemia such as haemorrhage, infections or iron deficiency. ${ }^{[7]}$ Study conducted on 32 individuals with alcohol dependence syndrome found that thrombocytopenia (41\%) was the most common haematological disturbance and $19 \%$ of the patients had anaemia. ${ }^{[8]}$ 
Alcohol interferes with the normal production and functions of white blood cells which form the body's defense against microorganisms and other foreign substances. Researchers have found that individuals with alcohol dependence commonly develop bacterial infections and alcohol-induced impairment of neutrophils and monocytes was most frequently observed. ${ }^{[9,10]}$ Studies have also observed reduced leukocyte count in blood and bone marrow as well as the decreased granulocyte reserve; and leukocyte count returned to normal within two weeks of abstinence without specific therapy. ${ }^{[11]}$ Several studies have found increased prevalence of pneumococcal bacteremia in individuals with alcohol dependence syndrome especially when leukopenia was present. ${ }^{[12,13,14]}$ Study conducted on a group of 34 individuals with alcohol dependence syndrome found a rise in reticulocytes count, a decrease in serum iron levels, increase in white blood cells counts especially with respect to the lymphocytes and an increase in serum Erythrocyte Sedimentation Rate. ${ }^{[15]}$

Researchers have observed impaired platelet function, low platelet count and diminished fibrinolysis in individuals with alcohol dependence syndrome. Several studies have found out that thrombocytopenia is a frequent complication in individuals with alcohol dependence syndrome affecting $3 \%$ to $43 \%$ of mild to moderate severity of alcohol dependence and $14 \%$ to $81 \%$ of severe alcohol dependence. ${ }^{[16,17,18]}$ Studies have reported that duration of dependence, amount of alcohol consumption, age of onset, history of withdrawal seizures and delirium has various effect on haematological component and was proportional to medical complications. Researchers have observed that thrombocytopenia may be caused by splenomegaly, folate deficiency and alcohol has direct toxic effect on production, survival time and functions of platelets. ${ }^{[19,20]} \mathrm{A}$ cohort study conducted on female and male patients aged more than 20 years, consecutively admitted to an alcohol treatment unit with diagnosis of alcohol dependence syndrome and alcohol dependence in withdrawal state found that individuals with delirium tremens had a increased prevalence of thrombocytopenia and those individuals with withdrawal seizures had lower blood platelet counts. The sensitivity and specificity of thrombocytopenia for the development of delirium tremens during the treatment period was $70 \%$ and $69 \%$, respectively. ${ }^{[21]}$ Researchers have also assessed platelet functions and platelet counts in patients with alcohol dependence on admission and during abstinence in hospital and observed that platelet aggregation and thromboxane A2 release returned to normal two to three weeks of abstinence. Platelet counts increased during abstinence. It is also reported that the impaired platelet function together with the reduced platelet count may contribute to the bleeding diathesis associated with alcohol dependence syndrome. ${ }^{[22,23]}$ Factors related to alcohol-related thrombocytopenia assessed in 43 patients with severe alcohol dependence found that the initial platelet counts was less than $100,000 / \mu 1$ in 15 patients; 100,000 to $150,000 / \mu 1$ in 20 patients; and over 150,000/ $\mu \mathrm{l}$ in 8 patients. Platelet count was monitored regularly and an increase from twofold to nineteen fold was observed in individuals who were abstinent from alcohol. ${ }^{[24]}$

\section{Aims of the Study}

1. To evaluate frequency and nature of haematological parameters in patients with Alcohol Dependence Syndrome.

2. To study the relationship between haematological parameters and clinical variables of alcohol dependence.

\section{Materials and Method}

The clinical study was conducted in the deaddiction centre, Department of Psychiatry, Father Muller Medical College, Mangalore. All patients admitted in the deaddiction centre from July 2012 to December 2012 constituted the population for the investigation. One hundred consecutive inpatients who satisfied the inclusion and exclusion criteria were selected as the sample for the study. The inclusion criteria were inpatients with ICD DCR-10 diagnosis of alcohol dependence syndrome, age group between 20 - 60 years, male patients. Patients with substance dependence other than nicotine, presence of comorbid psychiatric disorder; patients with medical comorbidity and pre existing haematological abnormalities were excluded from the study. For the present study, specially designed proforma was used to collect and document the sociodemographic and clinical data of alcohol dependence. Socio Economic Status Schedule [SESS - Sodhi and Sharma 1986] was used to assess the socioeconomic status of the patients. Assessment for haematological abnormalities in patients admitted with alcohol dependence syndrome included the laboratory investigations of hemoglobin, total leukocyte count, Erythrocyte Sedimentation Rate and platelet level estimation.

\subsection{Procedure}

The present investigation is an observational, descriptive, cross sectional clinical study. This study was cleared by the institutional ethical committee. The design and nature of the clinical study was explained to the patients and to significant relatives of patients. A written informed consent was obtained from all the subjects. All the patients $(n=100)$ were subjected to a thorough clinical examination which included physical and Mental Status Examination. When indicated extended neurological examination was carried out to rule out neurobehavioral disorders. The sociodemographic data was collected and recorded in the specially designed 
proforma. The socioeconomic class was assessed using the Socio Economic Status Schedule. Venous blood samples for laboratory investigations were sent on the day one of inpatient care. This included venous blood samples for hemoglobin, total leukocyte count, Erythrocyte Sedimentation Rate and platelet levels estimation. The diagnosis of haematological diseases was confirmed by consultants from general medicine. Collected data were analyzed by frequency, percentage, mean, standard deviations. The data was further analyzed using chisquare test, Fischer's Exact Test and Karl Pearson co-relation co-efficient.

\section{Results}

Of the 100 patients assessed with alcohol dependence syndrome, $16 \%$ belong to age group between 20 to 30 years, $40 \%$ to 31 to 40 years, $30 \%$ to 41 to 50 years and $15 \%$ belong to age group between 51 to 60 years respectively. $61 \%$ of individuals are married, $27 \%$ are single and $12 \%$ are separated/divorced. $64 \%$ of individuals belong to Hindu community, $5 \%$ to Muslim and $31 \%$ belong to Christian community respectively. $54 \%$ of the study sample resides in rural area and $46 \%$ in urban area. $26 \%$ of individuals are educated upto primary level, $38 \%$ upto high school, $17 \%$ upto PUC, $19 \%$ of individuals are graduate. $12 \%$ of individuals are unemployed, $38 \%$ are unskilled and $25 \%$ skilled labourer, $14 \%$ have clerical jobs and $11 \%$ are professionals. $13 \%$ of study sample belong to SESS class II, $47 \%$ to SESS class III and $40 \%$ to SESS class IV respectively.

Of the 100 inpatients with alcohol dependence syndrome who are assessed for haematological parameter $36 \%$ of individuals have hemoglobin level less than $12 \mathrm{~g} / \mathrm{dl}, 82 \%$ of individuals have total white blood cells count within normal range. $11 \%$ of individuals have an increase in white blood cells count and $7 \%$ of individuals have reduced white blood cells count. Erythrocyte Sedimentation Rate (ESR) is raised in $27 \%$ of individuals. $60 \%$ of individuals diagnosed with alcohol dependence syndrome have decreased platelet count.

$31.7 \%$ of individuals with alcohol dependence syndrome in withdrawal state and $43.2 \%$ of individuals with alcohol dependence syndrome in delirium have hemoglobin level less than $12 \mathrm{~g} / \mathrm{dl}$. Low hemoglobin levels are noted with increased duration of alcohol use and duration of dependence of alcohol. However, no statistically significance difference is noted. Individuals who consume more than 12 IU of alcohol per day are noticed to have low hemoglobin levels. Early onset of alcohol use is associated with low hemoglobin levels. $47.4 \%$ of individuals with past history of seizure and $48.4 \%$ of individuals with past history of delirium have reduced hemoglobin levels. However no statistically significant difference is noted. [Table 1]

Table 1: Association of Hemoglobin and Clinical variables

\begin{tabular}{|c|c|c|c|c|c|}
\hline & & $>12 \mathrm{~g} / \mathrm{dl}$ & $<12 \mathrm{~g} / \mathrm{dl}$ & Total & p value \\
\hline \multirow{2}{*}{$\begin{array}{l}\text { Psychiatric } \\
\text { Diagnosis }\end{array}$} & F 10.3 & $43(68.3 \%)$ & $20(31.7 \%)$ & $63(100 \%)$ & \multirow{2}{*}{$\begin{array}{l}0.248 \\
\text { NS }\end{array}$} \\
\hline & F10.4 & $21(56.8 \%)$ & $16(43.2 \%)$ & $37(100 \%)$ & \\
\hline \multirow{5}{*}{$\begin{array}{l}\text { Total Duration of } \\
\text { Alcohol Use }\end{array}$} & $0-5$ years & $5(62.5 \%)$ & $3(37.5 \%)$ & $8(100 \%)$ & \multirow{5}{*}{$\begin{array}{l}0.079 \\
\text { NS }\end{array}$} \\
\hline & $5-10$ years & $16(61.5 \%)$ & $10(38.5 \%)$ & $26(100 \%)$ & \\
\hline & $10-15$ years & $19(79.2 \%)$ & $5(20.8 \%)$ & $24(100 \%)$ & \\
\hline & $15-20$ years & $16(48.5 \%)$ & $17(51.5 \%)$ & $33(100 \%)$ & \\
\hline & $>20$ years & $8(88.9 \%)$ & $1(11.1 \%)$ & $9(100 \%)$ & \\
\hline \multirow{4}{*}{$\begin{array}{l}\text { Duration of } \\
\text { Dependence }\end{array}$} & $0-5$ years & $19(65.5 \%)$ & $10(34.5 \%)$ & $29(100 \%)$ & \multirow{4}{*}{$\begin{array}{l}0.266 \\
\text { NS }\end{array}$} \\
\hline & $5-10$ years & $23(69.7 \%)$ & $10(30.3 \%)$ & $33(100 \%)$ & \\
\hline & 10-15 Years & $14(50 \%)$ & $14(50 \%)$ & $28(100 \%)$ & \\
\hline & $>15$ years & $8(80 \%)$ & $2(20 \%)$ & $10(100 \%)$ & \\
\hline \multirow[t]{4}{*}{ Amount of Alcohol } & $<6 \mathrm{IU}$ & $1(100 \%)$ & 0 & $1(100 \%)$ & \multirow{4}{*}{$\begin{array}{l}0.776 \\
\text { NS }\end{array}$} \\
\hline & $6 \mathrm{IU}-12 \mathrm{IU}$ & $16(64 \%)$ & $9(36 \%)$ & $25(100 \%)$ & \\
\hline & $12 \mathrm{IU}-18 \mathrm{IU}$ & $28(68.3 \%)$ & $13(31.7 \%)$ & $41(100 \%)$ & \\
\hline & $>18 \mathrm{IU}$ & $19(57.6 \%)$ & $14(42.4 \%)$ & $33(100 \%)$ & \\
\hline \multirow[t]{2}{*}{ Age of Onset } & Early & $40(64.5 \%)$ & $22(35.5 \%)$ & $62(100 \%)$ & \multirow{2}{*}{$\begin{array}{l}0.891 \\
\text { NS }\end{array}$} \\
\hline & Late & $24(63.2 \%)$ & $14(36.8 \%)$ & $38(100 \%)$ & \\
\hline \multirow{2}{*}{$\begin{array}{ll}\text { Past } & \text { Withdrawal } \\
\text { seizures } & \\
\end{array}$} & Absent & $54(66.7 \%)$ & $27(33.3 \%)$ & $81(100 \%)$ & \multirow{2}{*}{$\begin{array}{l}0.251 \\
\mathrm{NS}\end{array}$} \\
\hline & Present & $10(52.6 \%)$ & $9(47.4 \%)$ & $19(100 \%)$ & \\
\hline \multirow{2}{*}{$\begin{array}{ll}\text { Past } & \text { Withdrawal } \\
\text { delirium } & \\
\end{array}$} & Absent & $48(69.6 \%)$ & $21(30.4 \%)$ & $69(100 \%)$ & \multirow{2}{*}{$\begin{array}{l}0.084 \\
\text { NS }\end{array}$} \\
\hline & Present & $16(51.6 \%)$ & $15(48.4 \%)$ & $31(100 \%)$ & \\
\hline
\end{tabular}

9.5\% of individuals with alcohol dependence syndrome in withdrawal state and $13.5 \%$ of individuals with alcohol dependence syndrome in delirium have increased white blood cells count. $6.3 \%$ of individuals with alcohol dependence syndrome in withdrawal state and $8.1 \%$ of individuals with alcohol dependence syndrome in delirium have decreased white blood cells count. $84.1 \%$ of individuals with alcohol dependence syndrome in withdrawal state and $78.4 \%$ of alcohol dependence syndrome in delirium have normal white blood cells count. No statistically significant differences are noted with clinical variables. [Table 2] 
Haematological Parameters in patients with Alcohol Dependence Syndrome.

Table 2: Association of White Blood Cells and Clinical Variables

\begin{tabular}{|c|c|c|c|c|c|c|}
\hline & & $\begin{array}{l}<4000 \\
\text { /cumm }\end{array}$ & $\begin{array}{l}4000- \\
11000 / \text { cumm }\end{array}$ & $>11000$ /cumm & Total & p value \\
\hline \multirow{2}{*}{$\begin{array}{l}\text { Psychiatric } \\
\text { Diagnosis }\end{array}$} & F 10.3 & $4(6.3 \%)$ & $53(84.1 \%)$ & $6(9.5 \%)$ & $63(100 \%)$ & \multirow{2}{*}{$\begin{array}{l}0.662 \\
\text { NS }\end{array}$} \\
\hline & F10.4 & $3(8.1 \%)$ & $29(78.4 \%)$ & $5(13.5 \%)$ & $37(100 \%)$ & \\
\hline \multirow{5}{*}{$\begin{array}{l}\text { Total duration } \\
\text { of alcohol use }\end{array}$} & $0-5$ years & 0 & $7(87.5 \%)$ & $1(12.5 \%)$ & $8(100 \%)$ & \multirow{5}{*}{$\begin{array}{l}0.623 \\
\mathrm{NS}\end{array}$} \\
\hline & $5-10$ years & $1(3.8 \%)$ & $22(84.6 \%)$ & $3(11.5 \%)$ & $26(100 \%)$ & \\
\hline & 10-15 years & $4(16.7 \%)$ & $16(66.7 \%)$ & $4(16.7 \%)$ & $24(100 \%)$ & \\
\hline & $15-20$ years & $2(6.1 \%)$ & $28(84.8 \%)$ & $3(9.1 \%)$ & $33(100 \%)$ & \\
\hline & $>20$ years & 0 & $9(100 \%)$ & 0 & $9(100 \%)$ & \\
\hline \multirow{4}{*}{$\begin{array}{l}\text { Duration of } \\
\text { dependence }\end{array}$} & $0-5$ years & $2(6.9 \%)$ & $25(86.2 \%)$ & $2(6.9 \%)$ & $29(100 \%)$ & \multirow{4}{*}{$\begin{array}{l}0.455 \\
\mathrm{NS}\end{array}$} \\
\hline & $5-10$ years & $2(6.1 \%)$ & $24(72.7 \%)$ & $7(21.2 \%)$ & $33(100 \%)$ & \\
\hline & 10-15 Years & $3(10.7 \%)$ & $23(82.1 \%)$ & $2(7.1)$ & $28(100 \%)$ & \\
\hline & $>15$ years & 0 & $10(100 \%)$ & 0 & $10(100 \%)$ & \\
\hline \multirow{4}{*}{$\begin{array}{l}\text { Amount of } \\
\text { alcohol }\end{array}$} & $<6 \mathrm{IU}$ & $1(100 \%)$ & 0 & 0 & $1(100 \%)$ & \multirow{4}{*}{$\begin{array}{l}0.214 \\
\text { NS }\end{array}$} \\
\hline & $6 \mathrm{IU}-12 \mathrm{IU}$ & $1(4 \%)$ & $20(80 \%)$ & $4(16 \%)$ & $25(100 \%)$ & \\
\hline & 12 IU- $18 \mathrm{IU}$ & $2(4.9 \%)$ & $34(82.9 \%)$ & $5(12.2 \%)$ & $41(100 \%)$ & \\
\hline & $>18 \mathrm{IU}$ & $3(9.1 \%)$ & $28(84.8 \%)$ & $2(6.1 \%)$ & $33(100 \%)$ & \\
\hline \multirow[t]{2}{*}{ Age of onset } & Early & $3(6.2 \%)$ & $53(85.5 \%)$ & $6(9.7 \%)$ & $62(100 \%)$ & \multirow{2}{*}{$\begin{array}{l}0.451 \\
\mathrm{NS}\end{array}$} \\
\hline & Late & $4(10.5 \%)$ & $29(76.3 \%)$ & $5(13.2 \%)$ & $38(100 \%)$ & \\
\hline \multirow{2}{*}{$\begin{array}{l}\text { Past } \\
\text { Withdrawal } \\
\text { seizures }\end{array}$} & Absent & $5(6.2 \%)$ & $68(84 \%)$ & $8(9.9 \%)$ & $81(100 \%)$ & \multirow{2}{*}{$\begin{array}{l}0.469 \\
\mathrm{NS}\end{array}$} \\
\hline & Present & $2(10.5 \%)$ & $14(73.7 \%)$ & $3(15.8 \%)$ & $19(100 \%)$ & \\
\hline \multirow{2}{*}{$\begin{array}{l}\text { Past } \\
\text { Withdrawal } \\
\text { delirium }\end{array}$} & Absent & $5(7.2 \%)$ & $57(82.6 \%)$ & $7(10.1 \%)$ & $69(100 \%)$ & \multirow{2}{*}{$\begin{array}{l}0.914 \\
\mathrm{NS}\end{array}$} \\
\hline & Present & $2(6.5 \%)$ & $25(80.6 \%)$ & $4(12.9 \%)$ & $31(100 \%)$ & \\
\hline
\end{tabular}

$23.8 \%$ of individuals with alcohol dependence syndrome in withdrawal state and $32.4 \%$ of individuals with alcohol dependence syndrome in delirium have raised Erythrocyte Sedimentation Rate. Increased Erythrocyte Sedimentation Rate is noted in $27.4 \%$ of individuals with early age of onset. Raised Erythrocyte Sedimentation Rate is noted in individual who consume more than 12 IU of alcohol per day. However, no statistically significance difference is noted. [Table 3]

Table 3: Association of Erythrocyte Sedimentation Rate and Clinical variables

\begin{tabular}{|c|c|c|c|c|c|}
\hline & & $\begin{array}{l}\text { Normal } \\
\text { (upto15mm/ } 1^{\text {st }} \text { hour) }\end{array}$ & Increased & Total & $p$ value \\
\hline \multirow{2}{*}{$\begin{array}{l}\text { Psychiatric } \\
\text { Diagnosis }\end{array}$} & F 10.30 & $48(76.2 \%)$ & $15(23.8 \%)$ & $63(100 \%)$ & \multirow{2}{*}{$\begin{array}{l}0.236 \\
\text { NS }\end{array}$} \\
\hline & F10.40 & $25(67.6 \%)$ & $12(32.4 \%)$ & $37(100 \%)$ & \\
\hline \multirow{5}{*}{$\begin{array}{l}\text { Total duration } \\
\text { of alcohol use }\end{array}$} & $0-5$ years & $6(75 \%)$ & $2(25 \%)$ & $8(100 \%)$ & \multirow{5}{*}{$\begin{array}{l}0.170 \\
\text { NS }\end{array}$} \\
\hline & $5-10$ years & $18(69.2 \%)$ & $8(30.8 \%)$ & $26(100 \%)$ & \\
\hline & $10-15$ years & $21(87.5 \%)$ & $3(12.5 \%)$ & $24(100 \%)$ & \\
\hline & $15-20$ years & $20(60.6 \%)$ & $13(39.4 \%)$ & $33(100 \%)$ & \\
\hline & $>20$ years & $8(88.9 \%)$ & $1(11.1 \%)$ & $9(100 \%)$ & \\
\hline \multirow{4}{*}{$\begin{array}{l}\text { Duration of } \\
\text { dependence }\end{array}$} & $0-5$ years & $21(72.4 \%)$ & $8(27.6 \%)$ & $29(100 \%)$ & \multirow{4}{*}{$\begin{array}{l}0.850 \\
\text { NS }\end{array}$} \\
\hline & $5-10$ years & $25(75.8 \%)$ & $8(24.2 \%)$ & $33(100 \%)$ & \\
\hline & 10-15 Years & $19(67.9 \%)$ & $9(32.1 \%)$ & $28(100 \%)$ & \\
\hline & $>15$ years & $8(80 \%)$ & $2(20 \%)$ & $10(100 \%)$ & \\
\hline \multirow{4}{*}{$\begin{array}{l}\text { Amount of } \\
\text { alcohol }\end{array}$} & $<6 \mathrm{IU}$ & $1(100 \%)$ & 0 & $1(100 \%)$ & \multirow{4}{*}{$\begin{array}{l}0.298 \\
\text { NS }\end{array}$} \\
\hline & $6 \mathrm{IU}-12 \mathrm{IU}$ & $19(76 \%)$ & $6(24 \%)$ & $25(100 \%)$ & \\
\hline & $12 \mathrm{IU}-18 \mathrm{IU}$ & $26(63.4 \%)$ & $15(36.6 \%)$ & $41(100 \%)$ & \\
\hline & $>18 \mathrm{IU}$ & $27(81.8 \%)$ & $6(18.2 \%)$ & $33(100 \%)$ & \\
\hline \multirow[t]{2}{*}{ Age of onset } & Early & $45(72.6 \%)$ & $17(27.4 \%)$ & $62(100 \%)$ & \multirow{2}{*}{$\begin{array}{l}0.904 \\
\text { NS }\end{array}$} \\
\hline & Late & $28(73.7 \%)$ & $10(26.8 \%)$ & $38(100 \%)$ & \\
\hline \multirow{2}{*}{$\begin{array}{l}\text { Past } \\
\text { Withdrawal } \\
\text { seizures }\end{array}$} & Absent & $59(72.8 \%)$ & $22(27.2 \%)$ & $81(100 \%)$ & \multirow{2}{*}{$\begin{array}{l}0.940 \\
\text { NS }\end{array}$} \\
\hline & Present & $14(73.7 \%)$ & $5(26.3 \%)$ & $19(100 \%)$ & \\
\hline \multirow{2}{*}{$\begin{array}{l}\text { Past } \\
\text { Withdrawal } \\
\text { delirium }\end{array}$} & Absent & $53(76.8 \%)$ & $16(23.2 \%)$ & $69(100 \%)$ & \multirow{2}{*}{$\begin{array}{l}0.200 \\
\text { NS }\end{array}$} \\
\hline & Present & $20(64.5 \%)$ & $11(35.5 \%)$ & $31(100 \%)$ & \\
\hline
\end{tabular}

$55.6 \%$ of individuals with alcohol dependence syndrome in withdrawal state and $67.6 \%$ of individuals with alcohol dependence syndrome in delirium have platelet level less than $150,000 /$ cumm. Reduced platelet count levels are noted with increase duration of alcohol use and duration of dependence of alcohol. However, no statistically significance difference is noted. Individual who consume more than 12 IU per day have low platelet levels. Low platelet levels are noted in individual with early onset of alcohol use. $73.7 \%$ of individuals with past history of seizure and $67.7 \%$ of individual with past history of delirium have reduced platelet levels. However, no statistically significant difference is noted. [Table 4] 
Haematological Parameters in patients with Alcohol Dependence Syndrome.

Table 4: Association of Platelet Count and Clinical Variables

\begin{tabular}{|c|c|c|c|c|c|}
\hline & & $>150,000$ /cumm & $<150,000 /$ cumm & Total & p value \\
\hline \multirow{2}{*}{$\begin{array}{l}\text { Psychiatric } \\
\text { Diagnosis }\end{array}$} & F 10.3 & $28(44.4 \%)$ & $35(55.6 \%)$ & $63(100 \%)$ & \multirow{2}{*}{$\begin{array}{l}0.236 \\
\mathrm{NS}\end{array}$} \\
\hline & F10.4 & $12(32.4 \%)$ & $25(67.6 \%)$ & $37(100 \%)$ & \\
\hline \multirow{5}{*}{$\begin{array}{l}\text { Total duration of } \\
\text { alcohol use }\end{array}$} & $0-5$ years & $2(25 \%)$ & $6(75 \%)$ & $8(100 \%)$ & \multirow{5}{*}{$\begin{array}{l}0.206 \\
\text { NS }\end{array}$} \\
\hline & $5-10$ years & $11(42.3 \%)$ & $15(57.7 \%)$ & $26(100 \%)$ & \\
\hline & $10-15$ years & $13(54.2 \%)$ & $11(45.8 \%)$ & $24(100 \%)$ & \\
\hline & $15-20$ years & $9(27.3 \%)$ & $24(72.7 \%)$ & $33(100 \%)$ & \\
\hline & $>20$ years & $5(55.6 \%)$ & $4(44.4 \%)$ & $9(100 \%)$ & \\
\hline \multirow{4}{*}{$\begin{array}{ll}\begin{array}{l}\text { Duration } \\
\text { dependence }\end{array} & \text { of }\end{array}$} & $0-5$ years & $11(37.9 \%)$ & $18(62.1 \%)$ & $29(100 \%)$ & \multirow{4}{*}{$\begin{array}{l}0.182 \\
\text { NS }\end{array}$} \\
\hline & $5-10$ years & $17(51.5 \%)$ & $16(48.5 \%)$ & $33(100 \%)$ & \\
\hline & 10-15 Years & $7(25 \%)$ & $21(75 \%)$ & $28(100 \%)$ & \\
\hline & $>15$ years & $5(50 \%)$ & $5(50 \%)$ & $10(100 \%)$ & \\
\hline \multirow{4}{*}{$\begin{array}{l}\text { Amount } \\
\text { alcohol }\end{array}$} & $<6 \mathrm{IU}$ & 0 & $1(100 \%)$ & $1(100 \%)$ & \multirow{4}{*}{$\begin{array}{l}0.574 \\
\mathrm{NS}\end{array}$} \\
\hline & $6 \mathrm{IU}-12 \mathrm{IU}$ & $10(40 \%)$ & $15(60 \%)$ & $25(100 \%)$ & \\
\hline & $12 \mathrm{IU}-18 \mathrm{IU}$ & $14(34.1 \%)$ & $27(65.9 \%)$ & $41(100 \%)$ & \\
\hline & $>18 \mathrm{IU}$ & $16(48.5 \%)$ & $17(51.5 \%)$ & $33(100 \%)$ & \\
\hline \multirow[t]{2}{*}{ Age of onset } & Early & $25(40.3 \%)$ & $37(59.7 \%)$ & $62(100 \%)$ & \multirow{2}{*}{$\begin{array}{l}0.933 \\
\text { NS }\end{array}$} \\
\hline & Late & $15(39.5 \%)$ & $23(60.5 \%)$ & $38(100 \%)$ & \\
\hline \multirow{2}{*}{$\begin{array}{l}\text { Past Withdrawal } \\
\text { seizures }\end{array}$} & Absent & $35(43.2 \%)$ & $46(56.8 \%)$ & $81(100 \%)$ & \multirow{2}{*}{$\begin{array}{l}0.176 \\
\text { NS }\end{array}$} \\
\hline & Present & $5(26.3 \%)$ & $14(73.7 \%)$ & $19(100 \%)$ & \\
\hline \multirow{2}{*}{$\begin{array}{l}\text { Past Withdrawal } \\
\text { delirium }\end{array}$} & Absent & $30(43.5 \%)$ & $39(56.5 \%)$ & $69(100 \%)$ & \multirow{2}{*}{$\begin{array}{l}0.289 \\
\text { NS }\end{array}$} \\
\hline & Present & $10(32.3 \%)$ & $21(67.7 \%)$ & $31(100 \%)$ & \\
\hline
\end{tabular}

\section{Discussion}

The present investigation is conducted in Father Muller Medical College Hospital which is a multispecialty general teaching hospital in Mangalore. The results of the present investigation indicate that haematological parameters are altered in individuals with alcohol dependence syndrome. It is observed that anaemia and thrombocytopenia are more common in individuals with alcohol dependence syndrome. In the present study $36 \%$ of individuals have low hemoglobin level, $82 \%$ of individuals have total white blood cells count within normal range. Erythrocyte Sedimentation Rate is raised in $27 \%$ of individuals. $60 \%$ of individuals diagnosed with alcohol dependence syndrome have decreased platelet count. The results of the study are in concordance with that of previous study.

Earlier studies have found that prolonged and excessive consumption of alcohol through direct or indirect effect suppress haematopoiesis in individuals with alcohol dependence leads to decrease in red blood cells, white blood cells and platelet counts. Previous investigators have found an increase prevalence of anaemia in individuals with alcohol dependence syndrome. The results of the present study are in concordance with that of the earlier studies. ${ }^{[3,4,5,6,7,8]}$ Earlier studies conducted on cohort of individuals with alcohol dependence have found to have raised Erythrocyte Sedimentation Rate especially in patient with alcohol liver disease. ${ }^{[15]}$ In the current investigation $23.8 \%$ of individuals with alcohol dependence syndrome in withdrawal state and $32.4 \%$ of individuals with alcohol dependence syndrome in delirium have raised Erythrocyte Sedimentation Rate. 27.4\% of individuals with early age of onset had increased Erythrocyte Sedimentation Rate. Raised Erythrocyte Sedimentation Rate is noted in individuals who consume more than 12 IU of alcohol per day.

Previous researchers have reported the association of leukopenia, pneumococcal sepsis in individuals with alcohol dependence syndrome. It is observed that excessive alcohol consumption predisposes the host to a wide range of infectious complications, particularly pulmonary infections. ${ }^{[9,10,11,12,13,14]}$ In the present study $6.3 \%$ of individuals with alcohol dependence syndrome in withdrawal state and $8.1 \%$ of individuals with alcohol dependence syndrome in delirium have decreased white blood cells count. In the current study $84.1 \%$ of individuals with alcohol dependence syndrome in withdrawal state and $78.4 \%$ of individuals with alcohol dependence syndrome in delirium have white blood cells count within the normal range. Although $9.5 \%$ of individuals with alcohol dependence syndrome in withdrawal state and $13.5 \%$ of individuals with alcohol dependence syndrome in delirium have increased white blood cells count.

The results of the present study indicates $55.6 \%$ of individuals with alcohol dependence syndrome in withdrawal state and $67.6 \%$ of individuals with alcohol dependence syndrome in delirium have platelet level less than 150,000/cumm. Reduced platelet count levels are noted with increase duration of alcohol use and duration of dependence of alcohol. Earlier studies have found increased prevalence of thrombocytopenia in individuals with alcohol dependence syndrome. ${ }^{[16,17,18]}$ In the current investigation low platelet level are noted in individual who consume alcohol more than $12 \mathrm{IU}$ per day. $73.7 \%$ of individuals with past history of seizure and $67.7 \%$ of individual with past history of delirium have low platelet levels. The results of the present study are in concordance with that of the earlier studies. ${ }^{[21]}$

In individuals with alcohol dependence syndrome differences in the quantity of alcohol consumption, inherited or acquired variations in haematological parameter may account for the differences in susceptibility. The effects may be exacerbated by the presence of other alcohol-related disorders, such as liver disease and 
Haematological Parameters in patients with Alcohol Dependence Syndrome.

nutritional deficiencies. The medical consequences of haematological abnormalities can be severe. It is observed anaemia which is more prevalent has debilitating effects and increased susceptibility for other medical complications. Previous researchers reported that alcohol-related thrombocytopenia is generally transient, and platelet counts usually return to normal within few weeks of abstinence. Patients generally require no therapeutic intervention other than management of alcohol dependence syndrome. Only in patients whose thrombocytopenia is severe and associated with excessive bleeding, platelet transfusions is indicated. ${ }^{[5]}$ Several studies have observed that abstinence from alcohol may reverse many of its effects on hematopoiesis and blood cells functioning. Early intervention and management of alcohol dependence syndrome along with management of comorbid medical condition is required.

The present investigation is an observational, descriptive, cross sectional clinical study. The present study has certain merits and limitations. The sample size is inadequate. The out patients are not investigated. Selection bias is avoided. The sample is not representative of the general population of such patients as the study was done in tertiary care hospital. A much larger representative sample with multiple centre approach would be suggested. Current investigation is a cross sectional analysis; longitudinal follow up study matched with control and correlation with other haematological parameters may provide larger scope for interpretation. Future studies are required to draw definite conclusions.

\section{Conclusion}

Prevalence of haematological abnormalities is higher in individuals with alcohol dependence syndrome. Our findings substantiate the importance for assessment of haematological parameters in patients with alcohol dependence syndrome.

\section{References}

[1]. E.R. Eichner. The hematologic disorders of alcoholism. The American Journal of Medicine.1973; 54(5):621-630

[2]. H.S. Ballard. The hematological complications of alcoholism. Alcohol Health \& Research World.1997; 21(1):42-52.

[3]. S.K. Das, D.M. Vasudevan. Biochemical diagnosis of alcoholism. Indian Journal of Clinical Biochemistry.2005; $20(1): 35-42$.

[4]. K. Seppa, P. Sillanaukee, T. Koivula. Abnormalities of hematologic parameters in heavy drinkers and alcoholics. Alcoholism Clinical \& Experimental Research.1992; 16(1):117-121.

[5]. F. Wisloff, D. Boman. Haemolytic anaemia in alcohol abuse. Journal of Internal Medicine.1979; 205(1-6):237-242

[6]. A. Walther, U. Poza, S. Salamanca, F. Mendieta, S. Heranz, E. Perez. Hematologic aspects of alcoholics. Medicina Clinica.1979; 72(4):158-165

[7]. E.R Eichner, R.S. Hillman. The evolution of anemia in alcoholic patients. American Journal of Medicine. 1971; 50(2):218-232

[8]. M. Bjorkholm. Immunological and hematological abnormalities in chronic alcoholism. Journal of Internal Medicine.1980; 207(16):197-200.

[9]. D.L. Hurley. Infectious complications of alcoholism. Journal of Postgraduate Medicine.1977; 61(5):160-162.

[10]. H.C. Adams, C. Jordan. Infections in the alcoholic. Medical Clinics of North America.1984; 68(1):179-200.

[11]. Y.K. Liu. Leukopenia in alcoholics. The American Journal of Medicine.1973; 54(5):605-610.

[12]. C.A. Perlino, D. Rimland. Alcoholism, leukopenia, and pneumococcal sepsis. American Review of Respiratory Disease.1985; 132(4):757-60.

[13]. R.T. Cook. Alcohol abuse, alcoholism, and damage to the immune system-a review. Alcohol Clinical Experimental Research.1998; 22(9):1927-1942.

[14]. N. Steve, Z. Ping, B.J. Gregory, H.I. Kyle, R.E. Caroline. Alcohol abuse, immunosuppression, and pulmonary infection. Current Drug Abuse Reviews.2008; 1(1):56-67.

[15]. M. Myrhed, L. Berglund, L.E. Bottiger. Alcohol consumption and hematology. Journal of Internal Medicine.1977; 202(1-6):11-15.

[16]. D.H. Cowan. The platelet defect in alcoholism. Annals of the New York Academy of Sciences.1975; 252:328-341.

[17]. D.H. Cowan. Effect of alcoholism on hemostasis. Seminars in Hematology.1980; 17(2):137-147.

[18]. P.C. Stanly, V.C. Wakwe, O.A. Ejele. Haematological profile in chronic alcohol consumers. Nigerian Journal of Clinical Practice.2003; 6(2):84-86.

[19]. S. Peltz. Severe thrombocytopenia secondary to alcohol use. Journal of Postgraduate Medicine.1991; 89(6):75-85.

[20]. A.H. Waters, A.A. Morley, J.G. Rankin. Effect of alcohol on haemopoiesis. British Medical Journal.1966; 2(5529):1565-1568.

[21]. U. Berggren, C. Fahlke, K.J. Berglund, K. Blennow, H. Zetterberg, J. Balldin. Thrombocytopenia in early alcohol withdrawal is associated with development of delirium tremens or seizures. Alcohol and Alcoholism.2009; 44 (4):382-386.

[22]. D.P. Mikhailidis, W.J. Jenkins, M.A. Barradas, J.Y. Jeremy, P. Dandona. Platelet function defects in chronic alcoholism. British Medicine Journal.1986; 293:715-718

[23]. J. Lindenbaum, R.L. Hargrove. Thrombocytopenia in alcoholics. Annals of Internal Medicine.1968; 68(3):526-532

[24]. D.H. Cowan, J.D. Hines. Thrombocytopenia of severe alcoholism. Annals of Internal Medicine.1971; 74(1):37-43. 